\title{
The Role and Application of Reflection in Service-Learning in Promoting Students' Learning in Higher Education
}

\author{
Hamdan Said ${ }^{1}$ \\ Iqbal Ahmad1 \\ Zubaidah Awang ${ }^{2}$ \\ Zainudin Hassan ${ }^{1}$ \\ ${ }^{1}$ Faculty of Education, Universiti Teknologi Malaysia \\ ${ }^{2}$ Language Academy, Universiti Teknologi Malaysia \\ p-hamdan@utm.my, shahnavi777@hotmail.com,m-zu@utm.my,p-zainudin@utm.my
}

Doi:10.5901/mjss.2015.v6n6s1p71

\section{Abstract}

Today, there is a growing belief among researchers and practitioners that reflection promotes students' learning and development in different ways. Despite this belief, the clear role of service-learning in enhancing learning is still debated. Although it is understood though with less clarity that reflection plays a key role in promoting learning, there is less clarity about the nature, types and practice of reflection in different contexts. There are different views on this subject from various quarters. There is much discussion in the current literature on reflection and its application in the developed world. However, less is known how reflection helps enhance students' learning in developing world context. The aim of this paper is to review the role and application of reflection in service-learning field in multiple contexts. In this regard, the paper extensively surveys works from different writers about the nature, type, models and application of reflection as a means for promoting learning. On the basis of the review of the current literature, the paper concludes that unlike conventional teaching approaches and irrespective of its contextual application and models used, reflection plays a key role in enabling students to challenge their own beliefs, test their own assumptions, create new knowledge and develop new ideas.

Keywords: reflection, role and application, student learning, service-learning

\section{Introduction}

In the last few decades, service-learning has enormously expanded as an academic discipline (Aberle-Grasse, 2000). It is believed that it effectively promotes academic learning, personal growth, civic and leadership skills among students (Deba, Jabor, Buntat, \& Musta'mal, 2014). In achieving this goal, the role of reflection is considered to be important. Reflection is one of the essential principles and elements of service-learning (Anson, 1997). Current literature reveals that reflection has been less highlighted due to which its importance has been overshadowed by other elements like reciprocity or diversity. Researchers have already claimed that reflection is closely connected with the aspect of learning, that is, one of the major aims of service-learning programmes (Ash \& Clayton, 2004). Secondly, there is a misconception about the practice of reflection during service-learning activity (Bowen, 2007). The main purpose of this paper is to clarify this misconception prevailing in the conception and practice of service-learning. The paper also attempts to highlight the real role of reflection and its implication for students' learning.

Reflection plays a key role in maximizing the learning. It helps in creating a real link and association between theory and practice (Ash, Clayton, \& Atkinson, 2005). It also basically serves as the important predictor for students' academic and personal outcomes. Despite of this, there is a general apprehension that the concept and nature of reflection has always remained a mystery among writers and practitioners of service-learning (Averill et al., 2007; Bringle $\&$ Hatcher, 1999). There is genuine need that this mystery must be explored and discussed so that the real potential of service-learning could be achieved (Carrington \& Selva, 2010; Welch \& James, 2007). 


\subsection{Purpose and methodology}

The main purpose of this review paper was to examine the role of reflection in promotion of student learning in higher education institutions. To achieve this objective, review research method was utilised and an extensive survey of the existing literature was carried out. The use of review research method helps in providing more extensive and reliable information on the issue (Gay, Mills, \& Airasian, 2011).

\section{Concept of Reflection}

Research has proved that reflection is crucial for maximization of learning. This understanding is based on the constructivist and experiential theories of learning (Ash et al., 2005; Bringle \& Hatcher, 1999). Amongst such important theories are that of David Kolb's learning cycle and Mezirow's model of transformational learning. In his experiential learning cycle theory, Kolb has suggested that learning is a constructive process and knowledge generation is based on certain processes (Carrington \& Selva, 2010). This process starts with a cycle and the first step in the cycle is concrete experience. It continues with other processes or steps in the cycle such as cognitive reflection and abstract theorization and finally active experimentation (Crossman \& Kite, 2007; Dubinsky, 2006).

The role of reflection can be easily seen in the practice of service-learning. Service-learning provides students with ample opportunities for concrete experiments and doing practice in the field in real life situations (Carrington \& Selva, 2010; Dunlap, 1998). This connects their learning experiences to concepts and theories further reinforcing learning, testing assumptions and generating new knowledge for future applications. At the same time, Mezirow's model of transformational learning basically focuses on bringing about changes in both the behaviour and learning of students (Anson, 1997).

This actually results from when they make sense of concept application through structured problem identification, critical discussion and looking for possible solutions (Eyler, 2002; Eyler, 2001). This goal is fairly achieved by servicelearning as it places the students in challenging situations. During this time, the students encounter structured problems, work as teams and try to solve it. This process, if facilitated by reflection and meaningful dialogue, ultimately it leads to the production of socially responsible behaviour and growth of student development (Eyler, 2002; Felten, Gilchrist, \& Darby, 2006).

This contention is generally supported by both Kolb and Mezirow. These theorists further highlight the importance of reflection in producing desired service-learning developmental outcomes for students (Gould \& Baldwin, 2004). Other researchers have further extended on the work of Kolb's learning cycle and Mezirow's transformational learning model. For example, it is suggested that research on reading comprehension provides some framework for using and promoting reflection in the service-learning (Hatcher \& Bringle, 1997). Literature on reading comprehension proposes that the prior knowledge of students if activated it helps as a key to understand the new concepts. This also involves students connecting the text to self and other texts to the wider world (Hatcher, Bringle, \& Muthiah, 2004). In the same way, service-learning helps in promoting learning by enabling the students to connect their classroom experiences to the real world situations and prior life experiences. In this way, students' learning is strengthened (Ikeda, 2000).

Deeper learning occurs when students successfully connect service-learning experiences with their own world just as connecting text to self and text to the world enhances the readers' literacy (Koth, 2003; Leming, 2000). Similarly, reflection enhances learning in the service-learning process. The theory of service-learning is based on the philosophical ideas of John Dewey. He calls learning a bilateral process where students connect their knowledge to life experiences. According to him, reflection is the main connector or bridge that connects the world of experience with the world of ideas. This is how real learning takes place where the learners apply their newly learnt knowledge to new experiences of life (Hatcher \& Bringle, 1997; Lo, 2009).

\section{Importance of Reflection}

Reflection is more than a notion in service-learning. It is a reflective thought that involves active, persistent and careful consideration of the available knowledge and beliefs, their bases and the consequences (Marchel, 2004). According to some researchers, reflection is a practice on the basis of which skills are acquired and feedback is provided. It allows the learners to adopt multifaceted ways for development and personal growth. It also impacts the construction of knowledge and develops effective habits of mind (McCaugherty, 1991; McClam, Diambra, Burton, Fuss, \& Fudge, 2008).

Apart from being a high level cognitive experience, reflection is also an emotional experience in which learners think critically and get involves in the experience more enthusiastically (Moffat \& Decker, 2000). Although so far little 
attention has been paid to emotion in the service-learning research work, for effective reflection, the emotional involvement of the learners in the learning process is very important (Molee, Henry, Sessa, \& McKinney-Prupis, 2010). Some writers believe that effective reflection relies on interrelationship between emotion and cognition. There is a need to direct the emotions of students during the performance of the service-learning (Panah, 2008). Emotions are the sources of motivation which is the foundation for effective learning. This means that reflection is bilateral action rather than merely an action as it works both as a processor and connector between theory and practice in any situation(Pusch \& Merrill, 2008).

The processing involves the rationalistic ways that students explore during the service activity in which they evaluate and re-evaluate their own beliefs, assumptions and practices (Quezada \& Christopherson, 2005). This helps connect the affective dimensions of learning with the experience. As a result, students develop deeper relationships not only among themselves but also understand the complex concepts and their applications in real life situations (Rhoads \& Howard, 1997). Thus here reflection plays the role of a connector or junction where rational, affective, thoughts and emotions interplay and provide more wider and meaningful opportunity to the students to internalize the concepts and understand the situation. Thus reflection becomes the source for transformation (Slivovsky, DeRego Jr, Zoltowski, Jamieson, \& Oakes, 2004). Reflectivity promotes new understanding of the situation, new state of mind and more informed course of action. The process of transformation strengthens further the roots of learning. This is the ultimate goal of education (Slivovsky et al., 2004).

\section{Model of Reflection}

Reflection is a key to learning. There are many models of learning, however, two models are very important in the process of service-learning (Ash et al., 2005; Eyler, 2002). These two models provide basic guidance to the instructors in the process of service about how to do reflection and relate to the learning experiences or effective use of reflection. In this regard, writers such as Eyler and Giles (1999) have suggested that good and effective reflection activities are characterized by five Cs such as connection between experience and knowledge; continuity of reflection before, during and after service; context of using the subject matter to the real life experiences of the learner; challenging the perspectives of students; and coaching the emotional support which is provided to the students during the process of service-learning.

Furthermore, some other researchers such as Hatcher et al. (2004) provide a parallel of this model. They have posited that reflective activities during service-learning should be clearly linked to the service experience and course content as well as learning objectives of the course. These must be structured in terms of description, expectations and criteria for assessment that is followed during the semester. In this way, students will find more time and space to examine the critical issues at deeper level and instructors would be able to provide feedback to students (Welch \& James, 2007).

Thus students will know how to improve the critical analysis and reflective practice. This will include more time for students to explore, clarify and even alter or change their personal beliefs, values and goals (Ash \& Clayton, 2004; Bowen, 2007). All these processes mentioned above would be clarified on the basis of these two models which are provided and used by instructors and leaders in the field of service-learning. This will also guide educators as to how to best known and support the development, growth of students and their learning in the service-learning by using reflection as a strategy (Rhoads \& Howard, 1997; Welch, 1999).

\section{Reflection and Learning}

Studies have indicated that structured and regular reflection in the process of service-learning helps improve the cognitive skills of students such as critical thinking, analysis, evaluation and decision-making (Deba, Jabor, Buntat, \& Musta'mal, 2014; Eyler, 2002). Reflection is a value which lays the real foundation for effective learning. Writers have suggested that during the service-learning activity, there is a need to focus on the nature of reflection activities rather than the quantity of activities. For effective processing of the course material, it is essential that instructors must give attention on processing the value sharing among students (Ash et al., 2005; Lo, 2009). This could be done on individual as well as collective basis. For this purpose, regular reflective activities will play a main role as it will broaden the opportunities for students for learning and development (Bowen, 2007; Slivovsky et al., 2004).

Some writers have recommended that instructors must use multiple reflection activities and modalities that may include products like classroom discussions, electronic discussions, field trips, directed readings, creative writings and artistic expressions (Anson, 1997; Hatcher et al., 2004). Some writers have concluded that for meaningful learning, 
structured thinking provides the foundation which can be done through reflection. This may contribute towards not only improving the service-behaviour but also learning (Felten et al., 2006; McClam et al., 2008).

In another study, it was found that reflective writing helped improve the reading comprehension and provided a theoretical framework for future work (Koth, 2003). The authors also found that using prompts and markers helped the instructors to teach students how to reflect meaningfully. Prompts are used as starting tools by students during writing activity and markers are used as tools for writing. The reflective content takes the students beyond mere writing to description of new ideas and possibilities and a new experience (Moffat \& Decker, 2000; Strouse, 2003).

Many researchers have recommended that instructors must discuss and develop writing activity plans and prompts for students so that they are able to connect the service to the text, situation and most importantly the course objectives (Ash et al., 2005). This will help the students to understand the connection between theory and practice and the role of reflection in it. In this regard, it must be made clear that students' reflection and feedback from the faculty members are very important to enhance the ability of students to learn to write meaningfully (Ash \& Clayton, 2004; Eyler, 2002).

\section{Practical Application of Reflection}

Reflection is conducted in service-learning in different ways (Eyler, 2001). For example, students describe their servicelearning experiences objectively, they answer the typical questions like who, when, where, whose, how and why (Averill et al., 2007; Bringle \& Hatcher, 1999). Students also try to examine the service experiences by using reflective prompts from various categories of the learning goals (Ash \& Clayton, 2004). The categories of the learning goal include personal growth, civic engagement, and academic engagement and enhancement. Thus it is necessary that reflection must be directed towards the personal growth of students. It must also be considered that during reflection, students must identify the strengths, weaknesses, assumptions and values during the service-learning activity (Hatcher \& Bringle, 1997; Slivovsky et al., 2004).

Students must also be able to discuss the effect of the activity on their personal growth and development as a result of service to others (Hatcher et al., 2004). As a result of civic engagement, students should be able to explain how they can bring about the required changes in the situation by using service as an opportunity (Ash et al., 2005; Ikeda, 2000). This exposes them to become effective change agents in the society which is another important goal of education. It is further believed that the goals of civic engagement are to accomplish needs of the community through service by describing and using various strategies and approaches to change (Quezada \& Christopherson, 2005; Welch, 1999).

The reflections which are designed to enhance the academic understanding are directed to explore and apply the relevant academic concepts, rely on the similarities and the differences, evaluating the need for rethinking the relevant concepts and speculating learning in their classroom situations as well as thinking how learning occurs (Moffat \& Decker, 2000; Strouse, 2003). During the reflective process, students actively articulate learning in their discussions how learning took place, what was the main purpose and why and how the new knowledge can be applied in new situations or real events of life (Ash \& Clayton, 2004). Another important aspect of the reflective practice is that even the instructors become partners in the process of learning rather than mere observers (McClam et al., 2008; Strouse, 2003). During reflection process, it is important that instructors must use time appropriately for discussion and evaluation of learning and service (Ash \& Clayton, 2004). This helps increases the possibility that students will become true shareholders in the process of service-learning rather than mere recipients (Aberle-Grasse, 2000; Slivovsky et al., 2004). Many writers have emphasized on the linking of service-learning outcomes with the goals of classroom learning such as civic development, academic growth and so on (Ash \& Clayton, 2004). During service-learning, the service aspect connects academic goals with community needs by effective reflection. For facilitating effective reflection, there is a need that the faculty members must ensure that service-learning activities are structured in such a way that support the desired knowledge, skill enhancement and value acquisition (Averill et al., 2007; Quezada \& Christopherson, 2005).

It must be bored in mind that once the outcomes are identified and specified, the activities must be structured to support desired learning, and to achieve this, the timing of the reflective practice should be determined (Slivovsky et al., 2004). Basically, reflection takes place before, during and after the service activity in various ways, and thus, it must be structured in different ways accordingly (Ash \& Clayton, 2004; Rhoads \& Howard, 1997). There is also a need to identify and use methods and define clear criteria for assessment. The method and the criterion must be well-articulated for students. This will help clarify the purpose, aim, ways and methods of doing reflections (Ash \& Clayton, 2004; Hatcher \& Bringle, 1997). 


\section{Conclusion}

On the basis of the above mentioned review, this paper concludes that reflection is useful tool for promoting learning. There are no fixed models for doing reflection. However, the paper found that instructors play key role in designing and implementing reflective activities. The paper also found that reflection is the necessary tool that creates a link between the new knowledge and its application in different contexts. Hence, the paper suggests that there is no hard and fast rule for reflection in developed and developing contexts. However, the duration and performance of reflection is an important aspect of service-learning. Hence the paper further advises that for properly doing reflection, it is necessary that specific objectives, well-structured service-learning activity, well timed ongoing reflective activity and clearly articulated assessment criterion must be made available to link the chain of service to learning and learning to service. The paper on the basis of the review argues that the importance of reflection in service-learning is evidenced by the fact that learning process is effectively characterized by reflective thoughts. The paper further concludes that reflection is a source for student awareness in the process of learning. It helps students to construct, modify, test, repair and enhance new knowledge acquired and its real application in the new context to solve human problems. In this way reflection becomes a tool both the development of students and achieving the goals of service-learning. The paper finally, argues that as a result of reflection, students challenge their own beliefs, test their own assumptions, create new knowledge and develop new ideas.

\section{References}

Aberle-Grasse, M. (2000). The Washington study-service year of Eastern Mennonite University reflections on 23 years of service learning. American Behavioral Scientist, 43(5), 848-857.

Anson, C. M. (1997). On reflection: The role of logs and journals in service-learning courses. In L. Adler-Kassner, R.Crooks, A. Watters (Eds), Writing the community: Concepts and models for service-learning in composition (pp. 167-180). Washington, DC: AAHE.

Ash, S. L., \& Clayton, P. H. (2004). The articulated learning: An approach to guided reflection and assessment. Innovative Higher Education, 29(2), 137-154.

Ash, S. L., Clayton, P. H., \& Atkinson, M. P. (2005). Integrating reflection and assessment to capture and improve student learning. Michigan Journal of Community Service Learning, 11(2), 49-60.

Averill, N. J., Sallee, J. M., Robinson, J. T., McFarlin, J. M., Montgomery, A. A., Burkhardt, G. A., \& Elam, C. L. (2007). A first-year community-based service learning elective: Design, implementation, and reflection. Teaching and Learning In Medicine, 19(1), 47-54.

Bowen, G. (2007). Reflection method and activities for service learning: A student manual and workbook. Dubuque, IA: Kendal/Hunt.

Bringle, R. G., \& Hatcher, J. A. (1999). Reflection in service learning: Making meaning of experience. Educational Horizons, 77, 179-185.

Carrington, S., \& Selva, G. (2010). Critical social theory and transformative learning: Evidence in pre-service teachers' service-learning reflection logs. Higher Education Research \& Development, 29(1), 45-57.

Crossman, J. M., \& Kite, S. L. (2007). Their perspectives: ESL students' reflections on collaborative community service learning. Business Communication Quarterly, 70(2), 147-165.

Deba, A. A., Jabor, M. K., Buntat, Y., Musta'mal, A. H. (2014). Potential of service-learning on students' interpersonal skills development in technical and vocational education. Asian Social Science, 10(21), 1-9.

Dubinsky, J. (2006). The role of reflection in service learning. Business Communication Quarterly, 69(3), 306-311.

Dunlap, M. R. (1998). Methods of supporting students' critical reflection in courses incorporating service. Teaching of Psychology, 25(3), 208-210.

Eyler, J. (2001). Creating your reflection map. New Directions for Higher Education, 2001(114), 35-43.

Eyler, J. (2002). Reflection: Linking service and learning—Linking students and communities. Journal of Social Issues, 58(3), 517-534.

Eyler, J., \& Giles, D. E. (1999). Where's the learning in service-learning? San Francisco, CA: Jossey-Bass.

Felten, P., Gilchrist, L. Z., \& Darby, A. (2006). Emotion and learning: Feeling our way toward a new theory of reflection in servicelearning. Michigan Journal of Community Service Learning, 12(2), 38-46.

Gay, L.R., Mills, G. E., \& Airasian, P. W. (2011). Educational research: Competencies for analysis and application (10th ed). New York, NY: Pearson.

Gould, N., \& Baldwin, M. (2004). Social work, critical reflection and the learning organisation. Aldershot: Ashgate.

Hatcher, J. A., \& Bringle, R. G. (1997). Reflection: Bridging the gap between service and learning. College Teaching, 45(4), 153-158.

Hatcher, J. A., Bringle, R. G., \& Muthiah, R. (2004). Designing effective reflection: What matters to service-learning? Michigan Journal of Community Service Learning, 11(1), 38-46.

Ikeda, E. (2000). How reflection enhances learning in service-learning courses. Paper presented at the American Educational Research Association (AERA), National Conference, New Orleans, LA.

Koth, K. (2003). Deepening the Commitment to Serve: Spiritual Reflection in Service-Learning. About Campus, 7(6), 2-7.

Leming, J. S. (2000). Integrating a structured ethical reflection curriculum into high school community service experiences: Impact on students' sociomoral development. Adolescence, 36(141), 33-45. 
Lo, W. Y. W. (2009). Reflections on internationalisation of higher education in Taiwan: Perspectives and prospects. Higher Education, 58(6), 733-745.

Marchel, C. A. (2004). Evaluating reflection and sociocultural awareness in service learning classes. Teaching of Psychology, 31(2), 120-123.

McCaugherty, D. (1991). The use of a teaching model to promote reflection and the experiential integration of theory and practice in firstyear student nurses: an action research study. Journal of Advanced Nursing, 16(5), 534-543.

McClam, T., Diambra, J. F., Burton, B., Fuss, A., \& Fudge, D. L. (2008). An analysis of a service-learning project: Students' expectations, concerns, and reflections. Journal of Experiential Education, 30(3), 236-249.

Moffat, J., \& Decker, R. (2000). Service-learning reflection for engineering: A faculty guide. In E. Tsang (ed), Design that matters: Concepts and models for service-learning in engineering (pp. 31-39). Washington, DC: AAHE

Molee, L. M., Henry, M. E., Sessa, V. I., \& McKinney-Prupis, E. R. (2010). Assessing learning in service-learning courses through critical reflection. Journal of Experiential Education, 33(3), 239-257.

Panah, K. (2008). Exploring patterns in teachers' conceptions of citizenship and political participation: A survey of secondary school teachers in Karachi, Pakistan. Journal of Research and Reflections in Education, 2(2), 103-120.

Pusch, M. D., \& Merrill, M. (2008). Reflection, reciprocity, responsibility, and committed relativism: Intercultural development through international service learning. In V. Savicki (Ed), Developing intercultural competence and transformation: Theory, research, and application in international education (pp. 297-321). Sterling, VA: Stylus.

Quezada, R. L., \& Christopherson, R. W. (2005). Adventure-based service learning: University students' self-reflection accounts of service with children. Journal of Experiential Education, 28(1), 1-16.

Rhoads, R. A., \& Howard, J. (1997). Academic service learning: A pedagogy of action and reflection. New Directions for Teaching and Learning (73): San Francisco, CA: Jossey-Bass.

Slivovsky, L. A., DeRego Jr, F. R., Zoltowski, C. B., Jamieson, L. H., \& Oakes, W. C. (2004). An analysis of the reflection component in the epics model of service learning. Paper presented at the Proceedings of the American Society for Engineering Education Annual Conference and Exposition, Salt Lake, UT.

Strouse, J. H. (2003). Reflection as a service-learning assessment strategy. Journal of Higher Education Outreach and Engagement, $8(2), 75-87$.

Welch, M. (1999). The ABCs of reflection: A template for students and instructors to implement written reflection in service-learning. NSEE Quarterly, 25(2), 23-25.

Welch, M., \& James, R. C. (2007). An investigation on the impact of a guided reflection technique in service-learning courses to prepare special educators. Teacher Education and Special Education: The Journal of the Teacher Education Division of the Council for Exceptional Children, 30(4), 276-285. 